International Journal of Managing Information Technology (IJMIT) Vol.10, No.1, February 2018

\title{
Structural Sources of A Productivity DECLINE IN THE DIGITAL ECONOMY
}

\author{
Chihiro Watanabe ${ }^{1,2}$, Kuniko Moriya $^{3}$, Yuji Tou ${ }^{4}$, Pekka Neittaanmäki $^{5}$ \\ ${ }^{1,5}$ Faculty of Information Technology,University of Jyväskylä, Finland \\ ${ }^{2}$ International Institute for Applied Systems Analysis (IIASA), Austria \\ ${ }^{3}$ Research and Statistics Department, Bank of Japan, Tokyo, Japan \\ ${ }^{4}$ Dept. of Ind. Engineering \&Magm., Tokyo Institute of Technology, Tokyo, Japan
}

\begin{abstract}
While the Internet-driven digitized innovation has provided us with extraordinary services and welfare, productivity in industrialized countries has been confronted with an apparent decline, and it has raised the question of a productivity paradox. The limitations of the GDP statistics in measuring the digital economy have become an important subject.

Based on national accounting framework and utilizing the development trajectories of 500 global information and communication technology (ICT) firms, structural sources of such decline were investigated. It was identified the two-faced nature of ICT that resulting in $R \& D$-intensive firms falling into a vicious cycle between $R \& D$ increase and marginal productivity of ICT decline.

Confronting such circumstances, $R \& D$-intensive firms have been endeavoring to transform into disruptive business model by harnessing the vigor of soft innovation resources. This transformation leads to spontaneous creation of uncaptured GDP and provides insightful suggestion to overcome the limitation of the GDP statistics in the digital economy.
\end{abstract}

\section{KEYWORDS}

Digital economy, productivity decline, limitation of GDP, two-faced nature of ICT, bipolarization

\section{INTRODUCTION}

The dramatic advancement of the Internet has generated the digital economy, which has changed the way of conducting business and daily lives [1]. The further progression of digitalized innovation over the last two decades, such as cloud, mobile services, and artificial intelligence, has augmented this change significantly and has provided us with extraordinary services and welfare never anticipated before [2]. However, contrary to such accomplishments, productivity in industrialized countries has been confronted with an apparent decline [3] [4] [5], and it has raised the question of a possible productivity paradox in the digital economy. The limitation of the GDP statistics in measuring the advancement of the digital economy have thus become an important subject [6] [7] [8].

There have been long-lasting debates on the information communication technology (ICT)-driven "productivity paradox."

Significant numbers of analyses demonstrated the impact of ICT on productivity triggered by Nobel Laureate Solow's "Productivity Paradox" [9] and reaction to it by Brynjolfsson [10]. Consequently,by the late 1990s, there were some signs that productivity had been improved by the introduction of ICT.

However, late in the first decade of this century, a new paradox appeared to have emerged. This can largely be attributed to the third industrial revolution initiated by the dramatic advancement of the Internet [11]. The Internet has changed the computer-initiated ICT world significantly. 
International Journal of Managing Information Technology (IJMIT) Vol.10, No.1, February 2018

Cowen [12] argued that, "Contrary to the dramatic advancement of the Internet and subsequent ICT advancement, we were living through the consequence of a dramatic decrease in the rate of innovation." He argued that the consequence of slowing innovation was fewer new industries and less creative destruction, hence fewer new jobs. He stressed that, while the technological progress brought a big and predictable stream of growth across most of the economy, those assumptions were turning out to be wrong or misleading when it came to the Internet. He then suggested the possibility of the consequence of the two-faced nature of ICT.

From the dramatic advancement of the Internet and subsequent third industrial revolution inevitably emerged a new paradox of the advancement of ICT. Brynjolfsson, who first reacted to Solow's production paradox in 1993, raised the question, "Could technology be destroying jobs?" [13]. He argued by giving an example of the music industry: "Because you and I stopped buying CDs, the music industry has shrunk, according to revenues and GDP. But we're not listening to less music. There's more music consumed than before" [14].

Inspired by these arguments, Lowrey [15] postulated that the Internet promotes more free culture, the consumption of which provides utility and happiness to people but cannot be captured through the GDP data that measure economic values.

Authors in previous studies stressed the significance of increasing dependence on uncaptured GDP by postulating that the Internet promotes a free culture that provides utility and happiness to people through its consumption but cannot be captured through GDP data, which measure economic values. ThisInternet-emergedadded valueofproviding people with utility and happiness, which extends beyond economic value, is defined as uncaptured GDP [16] [17] [18].

By realizing the two-faced nature of ICT as a consequence of a trap in ICT advancement, it was identified that advancement of ICT generally contributes to enhancing the prices of technology through new functionality development, as demonstrated by the iPhoneX, which was released in November 2017.

Note The prices of Apple's newest smartphones demonstrate the way in which price increase as functionality advances: iPhone 6S (US\$ 549), iPhone 7 (US\$ 649), iPhone8 (US\$ 699), iPhone8 plus (US\$ 799), and iPhoneX (US\$ 999).

However, contrary to traditional ICT, the dramatic advancement of the Internet has resulted in the decline of ICT prices because of the characteristics of freebies, easy and free replication, and mass standardization [16] [17].

The further advancement of digitized innovation as cloud, mobile services, and artificial intelligence, has accelerated permeation of the Internet into broad ICT.

Furthermore, driven by the Internet of Things (IoT), the physical world is becoming an ecosystem composed of physical objects embedded with sensors and actuators connected to applications and services through a wide range of networks. The IoT has the potential to drive the next steps toward the digitization of our society and economy [19].

Note Internet Society [20] defines the IoT as scenarios where network connectivity and computing capability extend to objects, sensors, and everyday items not normally considered computers, allowing these devices to generate exchanges and consume data with minimal human intervention.

Consequently, the Internet has been permeating into not only ICT general but also all production factors [21] leading to the continued drop in ICT prices.

This continued drop results in the declining marginal productivity of ICT in leading ICT firms provided that they seek profit maximum behavior in the competitive market.

Note : Given that firms seek profit maximization in a competitive market, their marginal ICT productivity corresponds to the relative price of ICT, and this marginal productivity is proportional to productivity (see Section 3). 
International Journal of Managing Information Technology (IJMIT) Vol.10, No.1, February 2018

Given that leading ICT firms take increasing initiative as the digital economy advances, such a decline in their marginal productivity cannot help declining productivity in the digital economy, which spread the limitation of GDP.

Confronting such circumstances, leading global ICT firms have been endeavoring to transform into a new business model that creates uncaptured GDP. This transformation can be considered a spontaneous creation of uncaptured GDP, not merely depending passively on the Internet-emerged uncaptured GDP, by harnessing the vigor of soft innovation resources including untapped resources utilization of which is not necessary within the reach of GDP accounting.

Thus, this model may provide insightful suggestion in overcoming the limitation of GDP. However, spontaneous creation dynamism and its possible contribution to overcome the limitation of the GDP statistics are yet unknown.

Following the preceding analyses, on the basis of national accounting framework confronting with an apparent decline, and utilizing the findings obtained from development trajectories of 500 global ICT firms over the period 2005-2016, this paper attempts to shed light on the unknown dynamism with respect to spontaneous creation of uncaptured GDP, and subsequent insightful suggestion to improve the GDP statistics for measuring the advancement of the digital economy.

Section 2 over reviews productivity decline in the digital economy. The structural sources of productivity decline in the digital economy is discussed in Section 3. Section 4 elucidates dynamism leading to productive decline and countermeasures against it. Section 5 summarizes the noteworthy findings, policy suggestions, and future research.

\section{Permeation of the Internet and Productivity Decline}

\subsection{Permeation Of The Internet Into Production Factors}

The dramatic advancement of the Internet and the further progression of digitized innovation over the last two decades, such as cloud services, mobile services, and artificial intelligence amidst the advancement of the digital economy have augmented the permeation of the Internet into broad ICT as illustrated in Fig. 1.

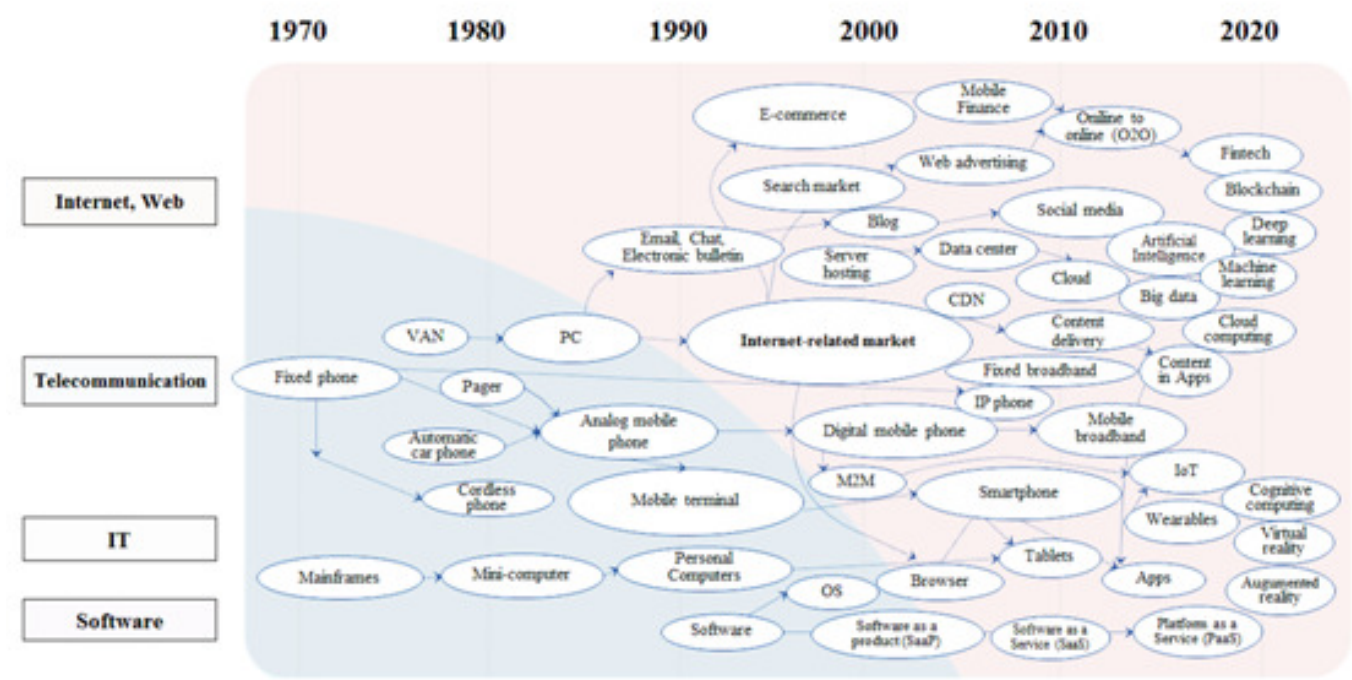

Figure 1. Illustration of the digital innovation initiated by the advancement of the Internet

Such permeation trend can be demonstrated by the converging trend of $R \& D$ related to the Internet and other ICT. 
International Journal of Managing Information Technology (IJMIT) Vol.10, No.1, February 2018

Technology stock both related to the Internet and other ICT can be estimated by the ratio of respective research and development (R\&D) expenditure and sum of rate of obsolescence of technology $(\rho)$ and increase rate of $R \& D$ at the initial period $(g)$, in the long run (see equation (5) in Section 4.1.1).

Fig. 2 traced the trend in the sum of $\rho+g$ in ICT related 27 key scientific research consisting of (i) Internet $R \& D$, (ii) Internet related peripheral $R \& D$, and (iii) other ICT $R \& D$ over the period 1980-2015.

Fig. 2demonstrates that while the sum of $\rho+g$ values were diverged by 2005, they have been converging toward 2010-2015 thereby technology stock both of the Internet and other ICT can be treated as a sum of both R\&D. This demonstrates the permeation trend of the Internet into broad ICT.

Note Analysis of Fig. 2 was based on the following bibliometrics approach:

The top $1 \%$ scientific paper in "Computer Science" and "Information Science \& Library Science" over the period 1960 -2015 was traced (altogether 14,438 scientific papers retrieved from the Web of Science provided by Clarivate Analytics were examined).

First, by using Academic Landscape System [22][23] a citation network was constructed. Second, by means of Newman method [24], the citation network was divided into 27 clusters. Each respective cluster contains more than 100 papers. Thus, top $1 \%$ scientific papers highlight 27 scientific fields in the broad ICT as illustrated in Fig. 2 which can be classified as (i) Internet R\&D ( 2 clusters), (ii) Internet related peripheral R\&D (8 clusters), and (iii) other ICT R\&D (17 clusters). $\rho$ can be estimated by calculating a reciprocal of the forward half-life after the peak with negative value, while $g$ can be estimated by calculating a reciprocal of the backward half-life before the peak with positive value (see Note 2 ).

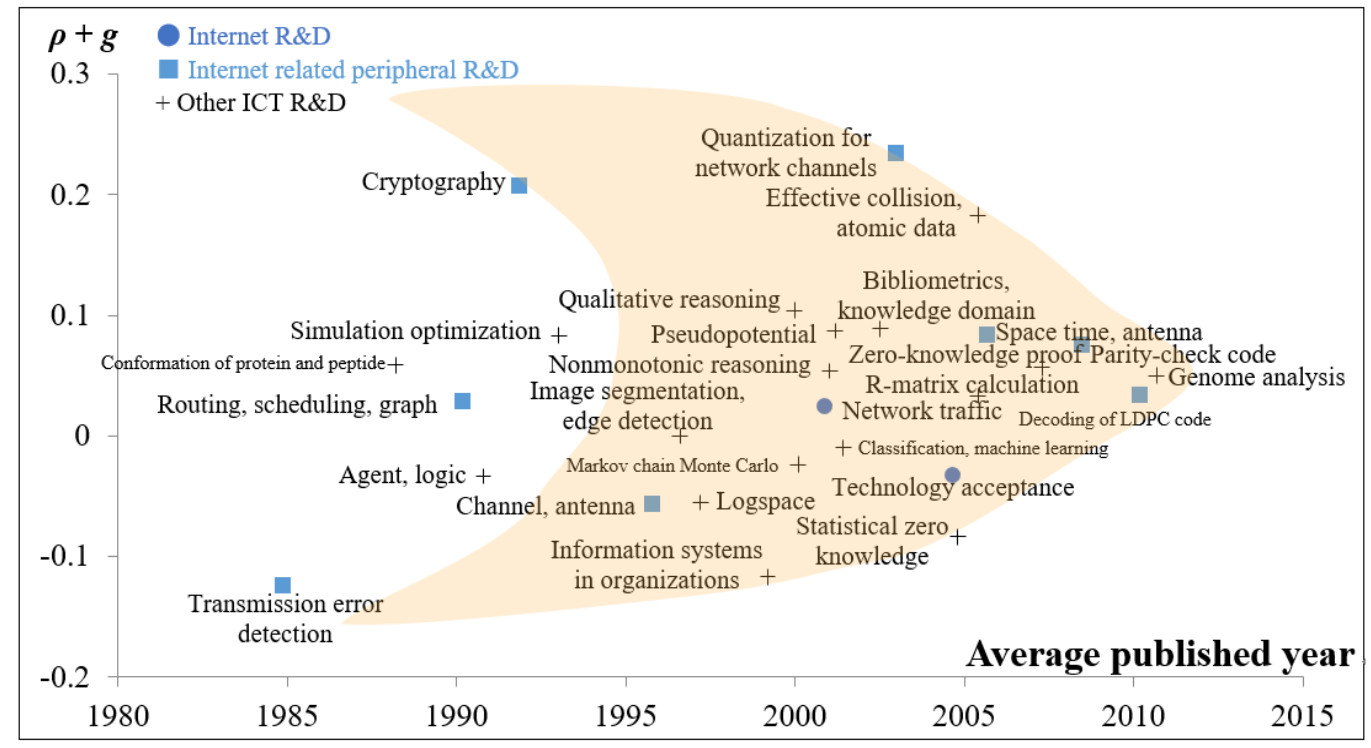

Figure 2. Trend in the sum of rate of obsolescence of technology and growth rate of R\&Dat the initial stage in Internet R\&D and other ICT R\&D (1980-2015). 
Note 2 Calculation Method

Number of publication

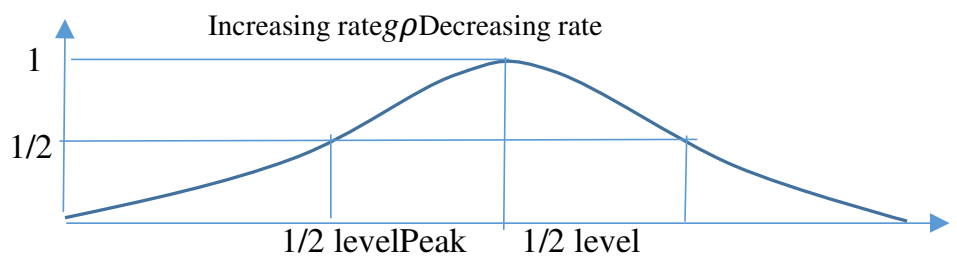

Furthermore, driven by the IoT, the physical world is becoming an ecosystem composed of physical objects embedded with sensors and actuators connected to applications and services through a wide range of networks. Consequently, the Internet has been permeating into not only ICTgeneral but also all production factors [21] toward an IoT-based society.

\subsection{Productivity Decline In The Digital Economy}

However, contrary to theseaccomplishments, productivity in industrialized countries has experienced a structural decline [3] [4] [5],as demonstrated in Fig. 3.This suggests a productivity paradox possibility in the digital economy as reviewed in Section 1.

US Council of Competitiveness revealed that productivity growth in the US continued to decline over the last five decades as illustrated in the top of Fig. 3. This is not only the US but also similar to the ICT advanced countries as illustrated in the middle of the Figure. The World Bank demonstrated that such decline can be observed also in certain non-industrialized countries as illustrated in the bottom of the Figure.

Productivity growth slowdown in the US(1966-2016) $\%$ Annual growth rate in real GDP per capita.
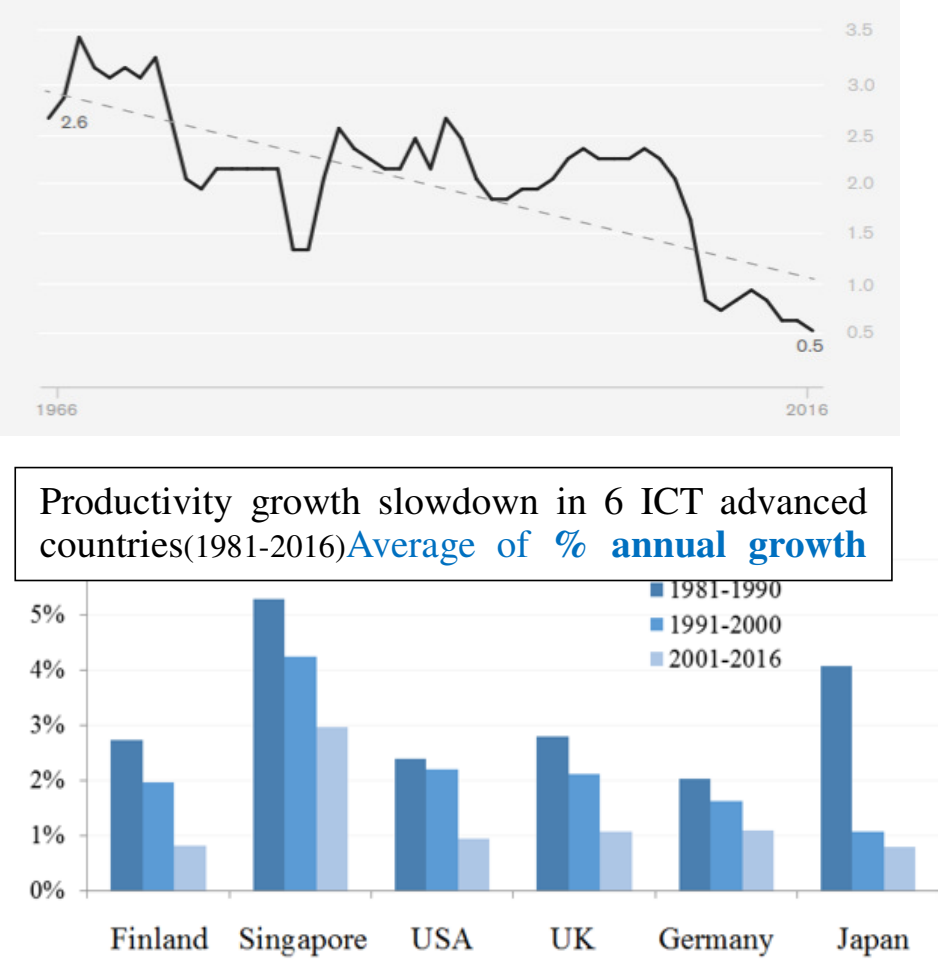


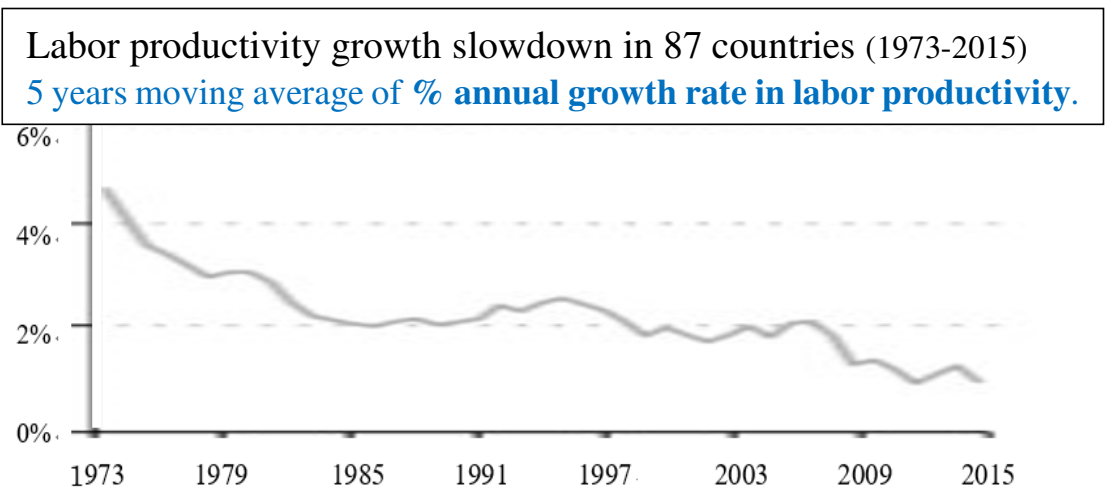

Figure3. Trend in productivity decline in the digital economy.

Sources: No Recovery: An Analysis on Long-term U.S Productivity Decline [4], Digital Dividends [5] and World Economic Outlook Database [25].

\section{Two-Faced Nature Of Ictleading Tothe Productivity Decline}

The majority of advanced ICT countries have been experiences extended stagnation ("great stagnation" [12]) in the digital economy as demonstrated by their low GDP growth from the middle of the first decade of this century as illustrated in Fig. 4.

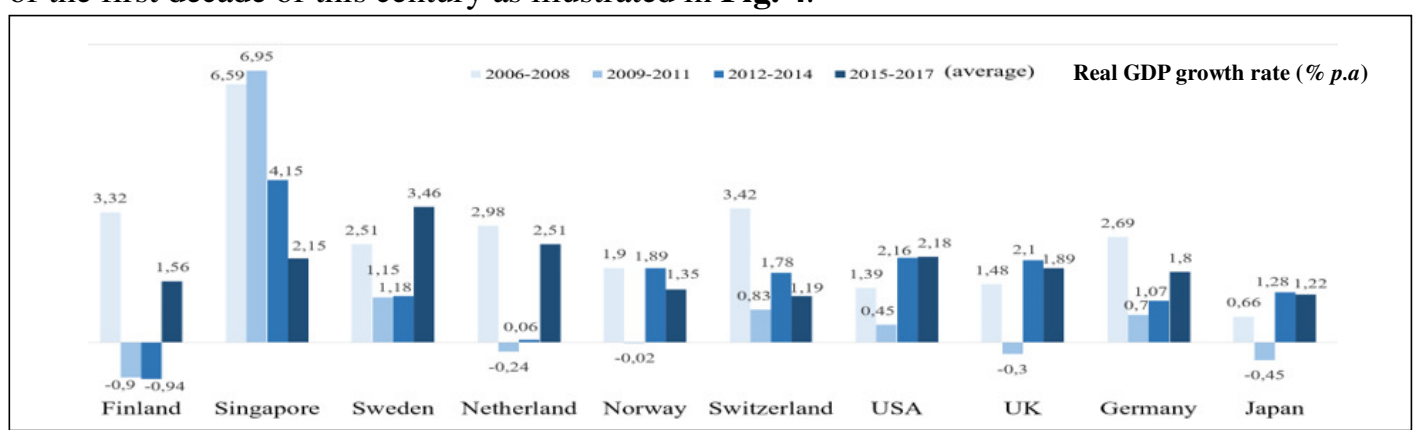

Figure 4. Stagnation in economic growth in ICT advanced countries (2006-2017).

Country order is based on the order of world ICT ranking in 2013 [26].

Source: World Economic Outlook Database [25].

Part of the stagnation itself can be attributed to a trap in ICT advancement derived from the two-faced nature of ICT, that is, while advancement of ICT generally contributes to enhanced prices of technology by new functionality development as reviewed in Section 1 and illustrated in Fig. 5, the dramatic advancement of the Internet reacts to decreased prices of technology due to its nature of freebies, easy and free replication, and mass standardization.

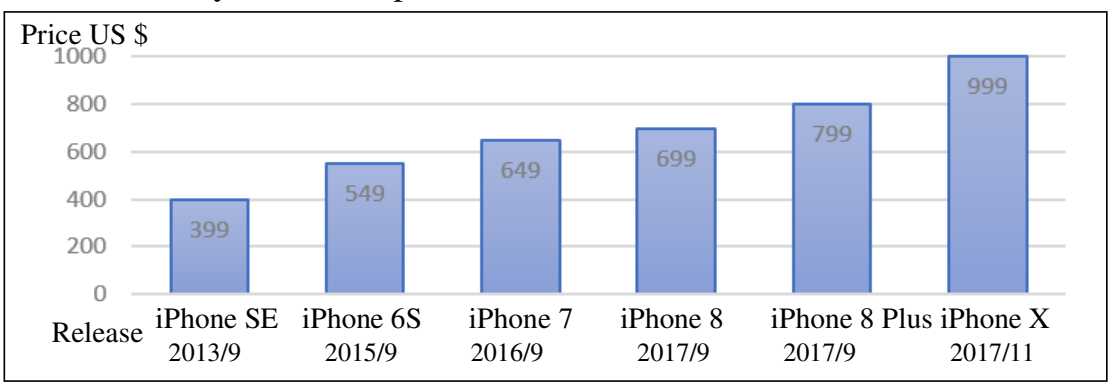

Figure 5. Trend in iPhone prices by function (2013-2017).

Source: Apple press release library. 
International Journal of Managing Information Technology (IJMIT) Vol.10, No.1, February 2018

As discussed in Section 1, the Internet promotes a free culture that provides utility and happiness to people through its consumption but cannot be captured through the GDP data, which measure economic values. These identical services are called uncaptured GDP, which occurs because of ICT's two-faced nature [16].

Fig. 6 illustrates this dynamismwith relevance to the GDP statistics in the digital economy which demonstrates bipolarization between price increase and decrease depending on the ICT advancement. Uncaptured GDP, which is illustrated in the top right of the figure, is produced through efforts to avoid and indemnify such price decrease by means of outsourcing price decreasing factors [16] and utilization of soft innovation resources including sleeping resources, trust, memory and future dream, and untapped resources [27].

Note Apple focuses its own resources on high value-added business such as design, planning, marketing and after-service while entrusting manufacturing which is relatively adds lower value to Japan and EMS (electronics manufacturing services) thereby maximizing the merit of international division and learning and absorption effects).
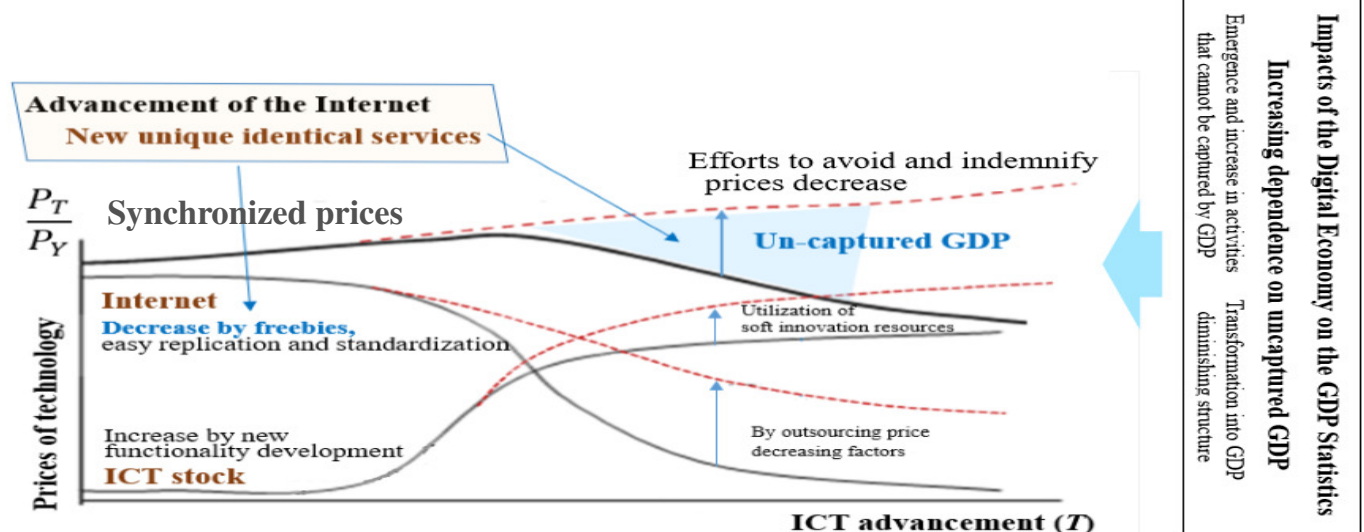

Figure 6. Dynamism of ICT price decrease as a consequence of its two-faced nature with relevance to the GDP statistics in the digital economy.

Original source: New Paradigm of ICT Productivity - Increasing Role of Uncaptured GDP and Growing Anger of Consumers [16].

Given that firms seek profit maximization in a competitive market, their marginal productivity of ICT corresponds to the relative price of ICT in terms of price of GDP, and the contribution of ICT to the growth rate can be attributed to the product of this marginal productivity and R\&D intensity ( $R \& D$ expenditure per sales). Therefore, the decrease in ICT price results in the stagnation of growth, as postulated by Cowen [12]. Fig. 7 illustrates scheme of this stagnation due to the decrease in ICT price.Since marginal productivity of ICT is proportional to ICT productivity (see Note) and given that the Internet has been permeating into not only ICTgeneral but also all production factors toward an IoT-based society as reviewed in Section 2.1, decline in marginal productivity of ICT stemmed from dramatic advancement of the Internet results in productivity decline in thedigital economy as reviewed in Section 2.2. 
International Journal of Managing Information Technology (IJMIT) Vol.10, No.1, February 2018

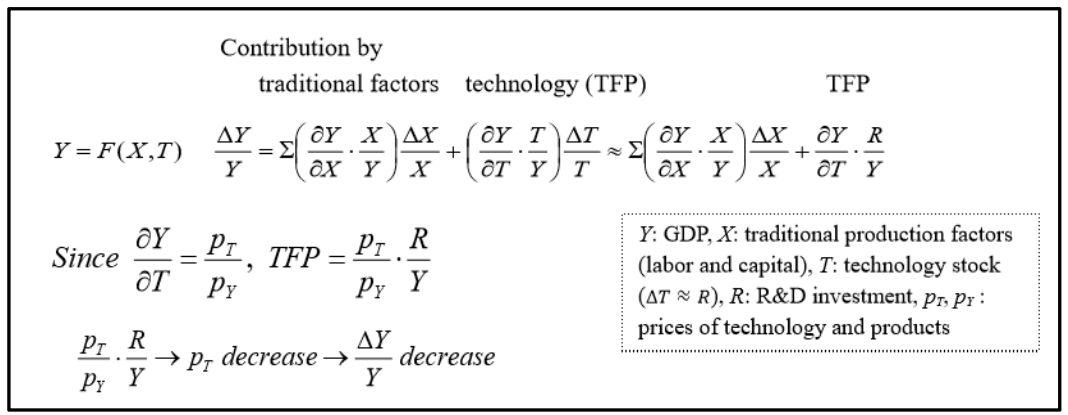

Figure 7. Scheme of the stagnation due to the decrease in ICT price.

Note : Elasticity is the measurement of how responsive an economic variable (e.g., $T$ ) is to a change in another (e.g., $Y$ ). The elasticity of $T$ to $Y(T$ elasticity to $Y) \varepsilon_{Y T}$ implies a $1 \%$ increase in $T$ increases $\varepsilon_{Y T} \%$ increase in $Y$ and represents the efficiency of $Y$ in the inducement of $T$.

Since $\epsilon_{Y T}=\frac{\partial \ln Y}{\partial \ln T}=\frac{\partial Y}{\partial T} \cdot \frac{T}{Y}$, Productivity $\frac{Y}{T}=\frac{1}{\epsilon_{Y T}} \cdot \frac{\partial Y}{\partial T}$ Therefore, given the certain period with stable elasticity, $T$ productivity is proportional to marginal productivity of $T$.

\section{Productivity Decline In Global ICT Firms}

In order to demonstrate the above hypothetical view, an empirical analysis focusing on the development trajectories of 500 global ICT firms(world top 500 firms by R\&D expenditure in the field of ICT relevant manufacturing and services) over the period 2005-2016 was conducted.

\subsection{ANALYTICAL FraMeWORK}

\subsubsection{Model Construction}

Following techno-economic analysis approach was used for the numerical analysis.

Digital value created by the global ICT firms in an IoT society can be depicted as follows:

$V=F\left(X, I_{g}\right)$

where $I_{\mathrm{g}}$ : gross ICT stock $=I($ ICT stock $)+J($ internet dependence $) ; X$ : other production factors. Translog (transcendental logarithmic) expansion on the first term:

$\ln V=p+q \ln X+r \ln I_{\mathrm{g}}$

where $p, q$, and $r$ : coefficients.

$I_{\mathrm{g}}$ embodies into $X$ in an IoT society as follows:

$X=F\left(I_{\mathrm{g}}\right) \quad \ln X=P_{\mathrm{x}}+r_{\mathrm{x}} \ln I_{\mathrm{g}}$

where $p_{\mathrm{x}}$ and $r_{\mathrm{x}}$ : coefficients.

Synchronizing equations (2) and (3):

$\ln V=p+q\left(P_{\mathrm{x}}+r_{\mathrm{x}} \ln I_{\mathrm{g}}\right)+r \ln I_{\mathrm{g}}=\left(p+q \cdot P_{\mathrm{x}}\right)+\left(q \cdot r_{\mathrm{x}}+r\right) \ln I_{\mathrm{q}} \equiv \alpha+\beta \ln I_{\mathrm{g}}$

where $\alpha=p+q \cdot P_{\mathrm{x}}, \beta=q \cdot r_{\mathrm{x}}+r$.

$V$ is governed by $I_{\mathrm{g}}$ under the above circumstances. 
International Journal of Managing Information Technology (IJMIT) Vol.10, No.1, February 2018

As the Internet permeates into ICT general, $I_{\mathrm{g}}$ increases proportional to gross R\&D (see Note).

$$
I_{\mathrm{g}}=I+J \approx \frac{R_{\mathrm{i}}}{\rho_{i}+g_{\mathrm{i}}}+\frac{R_{\mathrm{j}}}{\rho_{\mathrm{j}}+g_{\mathrm{j}}} \approx \frac{R_{\mathrm{i}}}{\rho+g}+\frac{R_{\mathrm{j}}}{\rho+g}=\frac{R_{\mathrm{i}}+R_{\mathrm{j}}}{\rho+g}=\frac{R}{\rho+g}
$$

where $R_{\mathrm{j}}: \mathrm{R} \& \mathrm{D}$ related to the Internet, and $R_{\mathrm{i}}: \mathrm{R} \& \mathrm{D}$ related to other ICT; $\rho:$ rate of obsolescence of ICT, and $g: R \& D$ growth rate at initial stage.

Substituting equation (5) for $I_{g}$ in equation (4):

$$
\ln V=\alpha+\beta \ln \frac{R}{\rho+g}=\alpha-\beta \ln (\rho+g)+\beta \ln R \equiv \alpha^{\prime}+\beta \ln R
$$

where $\alpha^{\prime}=\alpha-\beta \ln (\rho+g)$.

Thus, digital value is governed by gross R\&D in the global ICT firms in an IoT society.

Given the logistic growth nature of ICT, $V$ can be developed by an $R$-driven logistic growth function.

$$
V \approx F(R), \frac{d V}{d R}=\frac{\partial V}{\partial R} \cdot \frac{d R}{d R}=\frac{\partial V}{\partial R}=a V\left(1-\frac{V}{N}\right)
$$

where $N$ : carrying capacity; and $a$ : velocity of diffusion.

Equation (7) develops the following simple logistic growth function (SLG):

$$
V_{S}(R)=\frac{N}{1+b e^{-a R}}
$$

where $b$ : coefficient indicating the initial level of diffusion.

This function leads to bipolarization as follows:

$$
\begin{aligned}
& b e^{-a R} \equiv \frac{1}{x} \frac{\partial V}{\partial R}=a V\left(1-\frac{V}{N}\right)=a N \cdot \frac{1}{1+1 / x}\left(1-\frac{1}{1+1 / x}\right)=\frac{a N \cdot x}{(1+x)^{2}} \\
& \frac{d \frac{\partial V}{\partial R}}{d x}=\frac{d \frac{\partial V}{\partial R}}{d R} \cdot \frac{d R}{d x}=\frac{d \frac{\partial V}{\partial R}}{d R} \cdot \frac{1}{a x}=a N \cdot \frac{1-x}{(1+x)^{3}} \frac{1}{a x}=\frac{b}{a} e^{-a R}>0
\end{aligned}
$$

Digitalization exceeding certain $\mathrm{R} \& \mathrm{D}$ level $(R>\ln b / a)$ results in productivity decline.

$$
\frac{d \frac{\partial V}{\partial R}}{d R}=0 \Leftrightarrow x=1 \Leftrightarrow R=\frac{\ln b}{a} \rightarrow R>\frac{\ln b}{a} \Rightarrow \frac{d \frac{\partial V}{\partial R}}{d x}<0
$$

Thus, $\ln b / a$ indicates inflection point.

Note ICT stock at time $\mathrm{t}$ (where $m$ : time-lag between R\&D and commercialization):

$$
\begin{aligned}
I_{t}=R_{t-m}+(1 & -\rho) T_{t-1} \text { and } I_{0}=\frac{R_{1-m}}{\rho+g}, \text { therefore } I_{t}=\frac{R_{t+1-m}}{\rho+g}, \text { when } t \gg m-1, I_{t} \\
& \approx \frac{R_{t}}{\rho+g}
\end{aligned}
$$




\subsubsection{Data Construction}

Utilizing the EU Industrial R\&D Investment Scoreboard (EU) and annual reports of ICT firms, data necessary for the above numerical analyses for top 500 (by R\&D level) global ICT firms over the period 2005-2016 were constructed.Table 1 lists the top 70 R\&D-intensive global ICT firms in 2016 and compares their business performance by $\mathrm{R} \& \mathrm{D}(R)$, sales $(S)$, operating income $(O I), \mathrm{R} \& \mathrm{D}$ intensity $(R / S)$, profitability $(O I / S)$, and $R \& D$ profitability $(O I / R)$.

Table 1. Digital business structure in global ICT firms in 2016 (Top 70 R\&D-intensive ICT firms by R\&D level).

\begin{tabular}{|c|c|c|c|c|c|c|c|}
\hline $\begin{array}{l}\text { R\&D } \\
\text { level }\end{array}$ & Firm & $\begin{array}{c}\text { R\&D } \\
(R)\end{array}$ & $\begin{array}{c}\text { Net sales } \\
(S)\end{array}$ & $\begin{array}{c}\text { Operating } \\
\text { income } \\
(\mathrm{OI})\end{array}$ & $\mathrm{R} / \mathrm{S}$ & OI/S & OI/R \\
\hline & & EUR mil & EUR mil & EUR mil & $\%$ & $\%$ & $\%$ \\
\hline 1 & Samsung & 12528 & 157190 & 20692 & 8.0 & 13.2 & 165.2 \\
\hline 2 & Intel & 11140 & 50845 & 13016 & 21.9 & 25.6 & 116.8 \\
\hline 3 & Google & 11054 & 68879 & 17783 & 16.0 & 25.8 & 160.9 \\
\hline 4 & Microsoft & 11011 & 78369 & 18683 & 14.1 & 23.8 & 169.7 \\
\hline 5 & Huawei & 8358 & 55893 & 6479 & 15.0 & 11.6 & 77.5 \\
\hline 6 & Apple & 7410 & 214674 & 65427 & 3.5 & 30.5 & 883.0 \\
\hline 7 & Cisco & 5701 & 45235 & 11875 & 12.6 & 26.3 & 208.3 \\
\hline 8 & Oracle & 5316 & 34029 & 12036 & 15.6 & 35.4 & 226.4 \\
\hline 9 & Qualcomm & 5043 & 23221 & 5451 & 21.7 & 23.5 & 108.1 \\
\hline 10 & Siemens & 4820 & 75636 & 5809 & 6.4 & 7.7 & 120.5 \\
\hline 11 & IBM & 4515 & 75081 & 14586 & 6.0 & 19.4 & 323.1 \\
\hline 12 & Facebook & 4424 & 16467 & 5718 & 26.9 & 34.7 & 129.3 \\
\hline 13 & Ericsson & 3806 & 26870 & 2356 & 14.2 & 8.8 & 61.9 \\
\hline 14 & Sony & 3569 & 61787 & 2243 & 5.8 & 3.6 & 62.8 \\
\hline 15 & Panasonic & 3429 & 57559 & 2797 & 6.0 & 4.9 & 81.6 \\
\hline 16 & HP & 3217 & 94934 & 7353 & 3.4 & 7.7 & 228.6 \\
\hline 17 & LG & 2718 & 44269 & 934 & 6.1 & 2.1 & 34.4 \\
\hline 18 & SAP & 2689 & 20793 & 4252 & 12.9 & 20.4 & 158.1 \\
\hline 19 & Hitachi & 2544 & 76461 & 4597 & 3.3 & 0.1 & 180.7 \\
\hline 20 & Canon & 2504 & 28968 & 2708 & 8.6 & 9.3 & 108.1 \\
\hline 21 & Nokia & 2502 & 13574 & 1842 & 18.4 & 13.6 & 73.6 \\
\hline 22 & EMC & 2437 & 22691 & 3023 & 10.7 & 13.3 & 124.0 \\
\hline 23 & Alcatel & 2409 & 14280 & 890 & 16.9 & 6.2 & 36.9 \\
\hline 24 & Medtronic & 2043 & 26484 & 4860 & 7.7 & 18.4 & 237.9 \\
\hline 25 & ZTE & 1954 & 14176 & 955 & 13.8 & 6.7 & 48.9 \\
\hline 26 & Taiwan SEM & 1827 & 23508 & 9104 & 7.8 & 38.7 & 498.4 \\
\hline 27 & SK Hynix & 1543 & 14726 & 4180 & 10.5 & 28.4 & 270.9 \\
\hline 28 & West Digital & 1494 & 11935 & 754 & 12.5 & 6.3 & 50.5 \\
\hline 29 & Hon Hai & 1463 & 124916 & 5219 & 1.2 & 4.2 & 356.7 \\
\hline 30 & Baidu & 1444 & 9393 & 1651 & 15.4 & 17.6 & 114.3 \\
\hline 31 & Mitsubishi & 1426 & 33497 & 2296 & 4.3 & 6.9 & 161.0 \\
\hline 32 & Micron Tec & 1415 & 14873 & 2756 & 9.5 & 18.5 & 194.9 \\
\hline 33 & MediaTek & 1380 & 5943 & 727 & 23.2 & 12.2 & 52.6 \\
\hline 34 & Fujitsu & 1371 & 36126 & 1113 & 3.8 & 3.1 & 81.1 \\
\hline 35 & Applied Mat & 1332 & 8872 & 1387 & 15.0 & 15.6 & 104.1 \\
\hline
\end{tabular}

\begin{tabular}{|c|c|c|c|c|c|c|c|}
\hline $\begin{array}{l}\text { R\&D } \\
\text { level }\end{array}$ & Firm & $\begin{array}{c}\text { R\&D } \\
(R)\end{array}$ & $\begin{array}{c}\text { Net Sales } \\
\text { (S) }\end{array}$ & $\begin{array}{c}\text { Operating } \\
\text { income } \\
(O I)\end{array}$ & $\mathrm{R} / \mathrm{S}$ & OI/S & $\mathrm{OI} / \mathrm{R}$ \\
\hline & & EUR mil & EUR mil & EUR mil & $\%$ & $\%$ & $\%$ \\
\hline 36 & Lenovo & 1285 & 41253 & -20 & 3.1 & -0.05 & -1.6 \\
\hline 37 & Fujifilm & 1243 & 18993 & 1457 & 6.5 & 7.7 & 117.3 \\
\hline 38 & NVidia & 1223 & 4602 & 806 & 26.6 & 17.5 & 66.0 \\
\hline 39 & Tencent & 1177 & 14555 & 5717 & 8.1 & 39.3 & 485.5 \\
\hline 40 & Texas Inst & 1176 & 11941 & 3946 & 9.8 & 33.0 & 335.6 \\
\hline 41 & STM & 1149 & 6335 & 121 & 18.1 & 1.9 & 10.6 \\
\hline 42 & Danaher & 1138 & 18888 & 3298 & 6.0 & 17.5 & 289.8 \\
\hline 43 & Seagate & 1136 & 10251 & 409 & 11.1 & 4.0 & 36.0 \\
\hline 44 & Yahoo! & 1110 & 4564 & -4266 & 24.3 & -93.5 & -384.2 \\
\hline 45 & ASML & 1046 & 6287 & 1861 & 16.6 & 29.6 & 177.8 \\
\hline 46 & Elec Arts & 1019 & 4038 & 825 & 25.2 & 20.4 & 81.0 \\
\hline 47 & Sharp & 992 & 18764 & -1423 & 5.3 & -7.6 & -143.5 \\
\hline 48 & eBay & 973 & 7892 & 2018 & 12.3 & 25.6 & 207.5 \\
\hline 49 & Marvell & 968 & 2504 & -750 & 38.7 & -30.0 & -77.5 \\
\hline 50 & Broadcom & 964 & 6268 & 1534 & 15.4 & 24.5 & 159.2 \\
\hline 51 & NEC & 945 & 21505 & 743 & 4.4 & 3.5 & 78.6 \\
\hline 52 & Schneider & 937 & 26640 & 2220 & 3.5 & 8.3 & 236.9 \\
\hline 53 & Juniper & 913 & 4462 & 837 & 20.5 & 18.8 & 91.6 \\
\hline 54 & Salesforce & 875 & 6124 & 102 & 14.3 & 1.7 & 11.7 \\
\hline 55 & Cerner & 870 & 4065 & 717 & 21.4 & 17.7 & 82.4 \\
\hline 56 & Adv. Micro & 870 & 3666 & -308 & 23.7 & -8.4 & -35.4 \\
\hline 57 & Sumitomo & 845 & 22358 & 999 & 3.8 & 4.5 & 118.2 \\
\hline 58 & Twitter & 826 & 2037 & -413 & 40.6 & -20.3 & -50.0 \\
\hline 59 & Freescale & 817 & 4108 & 694 & 19.9 & 0.2 & 84.9 \\
\hline 60 & Infineon & 817 & 5795 & 557 & 14.1 & 9.6 & 68.2 \\
\hline 61 & Boston Sci & 805 & 6868 & 944 & 11.7 & 13.7 & 117.4 \\
\hline 62 & LinkedIn & 802 & 2747 & -139 & 29.2 & -5.0 & -17.3 \\
\hline 63 & Adobe & 792 & 4405 & 831 & 18.0 & 18.9 & 104.9 \\
\hline 64 & NetApp & 791 & 5094 & 426 & 15.5 & 8.4 & 53.9 \\
\hline 65 & Ricoh & 778 & 15357 & 960 & 5.1 & 0.1 & 123.4 \\
\hline 66 & SanDisk & 768 & 5112 & 698 & 15.0 & 13.7 & 90.9 \\
\hline 67 & LAM & 753 & 5406 & 987 & 13.9 & 18.3 & 131.0 \\
\hline 68 & Midea & 745 & 18063 & 1845 & 4.1 & 10.2 & 247.7 \\
\hline 69 & Renesas & 742 & 5285 & 788 & 14.0 & 14.9 & 106.2 \\
\hline 70 & NXP & 734 & 5604 & 691 & 13.1 & 12.3 & 94.1 \\
\hline
\end{tabular}

Note: Amazon is not presented because it did not meet the criteria of top 70 R\&D-intensive firms in 2016, as its position was $95^{\text {th }}$. The same applies to GE, Toshiba and Alibaba.

Sources: The EU Industrial R\&D Investment Scoreboard [28], Annual reports of ICT firms (annual issues).

\subsection{EMPIRICAL ANALYSIS}

Based on this analytical framework, development trajectory of global ICT firms over the period 2005-2016 was analyzed focusing on their productivity decline and countermeasures against it.

\subsubsection{Digital Value Representing The Behavior Of Global ICT Firms}

It is generally understood that market value, sales and operating income represent digital value created by the global ICT firms in an IoT society [21]. While market value is highly subject to external factors, sales and operating income represent dynamism inducing firms' R\&D-driven $(R$-driven) countermeasures against the above critical situation. 
International Journal of Managing Information Technology (IJMIT) Vol.10, No.1, February 2018

Therefore, by means of equation (6), comparative assessment of the correlation between R\&D investment and digital value taking sales and operating incomein 2016 was conducted first. Table 2 summarizes the result of the assessment.

Table 2. Comparative assessment of the correlation between $R \& D$ and digital value in 500 global ICT firms (2016).

$$
\begin{gathered}
\ln S=\underset{(4.43)}{2.319}+\underset{(15.18)}{0.997} D_{1} \ln R+1.013 D_{2} \ln R+1.023 D_{3} \ln R+2.903 \text { Dadj. } R^{2} 0.632 \\
\ln \mathrm{OI}=\underset{(-0.18)^{*}}{-1.280}+\underset{(11.77)}{1.048} D_{1} \ln R+\underset{(9.39)}{1.050} D_{2} \ln R+1.065 D_{3} \ln R+2.334 \text { Dadj. } R^{2} 0.525
\end{gathered}
$$

$S$ : Sales, OI: Operating income, $R$ : R\&D investment, $D_{1}, D_{2}, D_{3}$, and $D$ : dummy variables.

$D_{1}$ : High R\&D-intensive firms $=1$, other firms $=0$. Similarly, $D_{2}$ : R\&D-intensive firms $=1, D_{3}$ : Low R\&D-intensive firms $=1$, and $D$ : Outliers $=1$ (see classification of dummy variables in Fig. $8)$.

The figures in parentheses indicate t-statistics: All are significant at the $1 \%$ level, except $*$ is not significant.

Table 2 demonstrates that sales represents $R$-driven digital value creation behavior in the 500 global ICT firms better than operating income.In addition, it suggests that elasticity decreases as $R$-driven development proceeds similar to sigmoid curve in logistic growth.

With this result in mind Fig. 8 illustrates $R$-driven growth in 500 global ICT firms in 2016 demonstrated by sales increase.

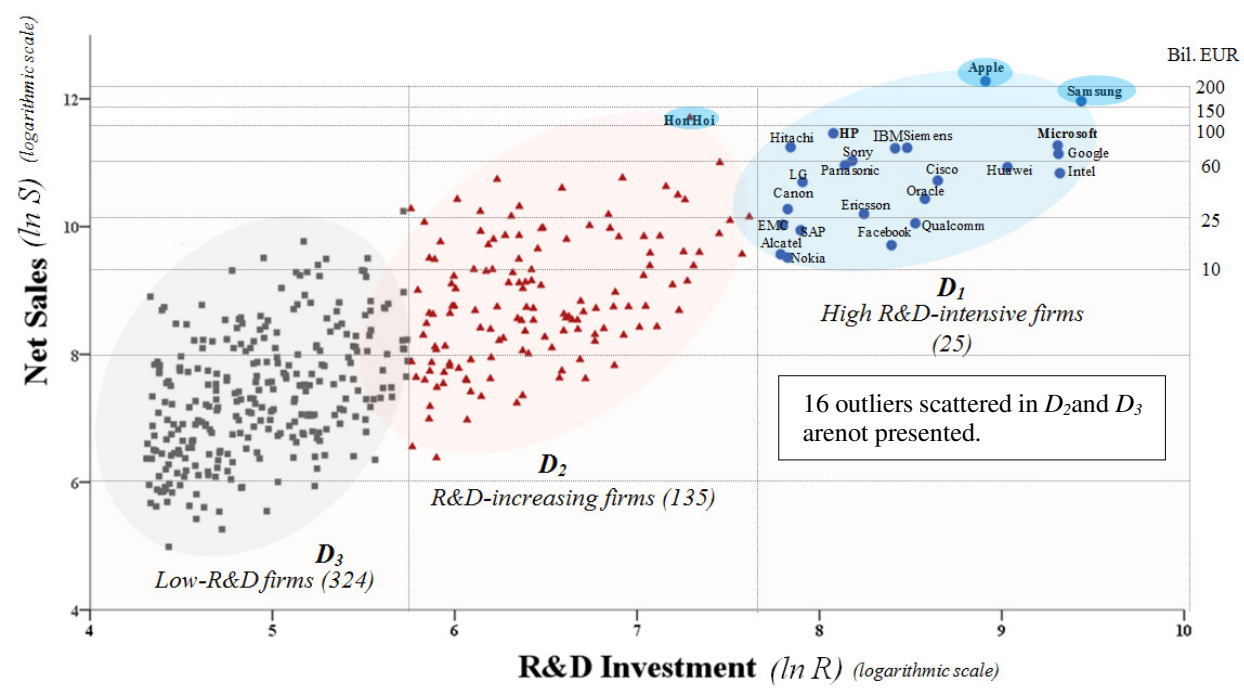

Figure8. R\&D-driven growth in 500 global ICT firms(2016).

\subsubsection{Specific Features of Global ICT Firms}

Based on these findings, in proceeding to further analysis on the development trajectory of global ICT firms focusing on their productivity decline, careful consideration was made with respect to specific features of global ICT firms.

While digital innovation accelerates logistic growth of global ICT firms induced by logistic growth nature of ICT[29], this innovation emerges "mutation" firms with outlying behavior. They are 
International Journal of Managing Information Technology (IJMIT) Vol.10, No.1, February 2018

generally newly founded young firms but expand at tremendous pace as demonstrated in Fig. 9 and Table 3.
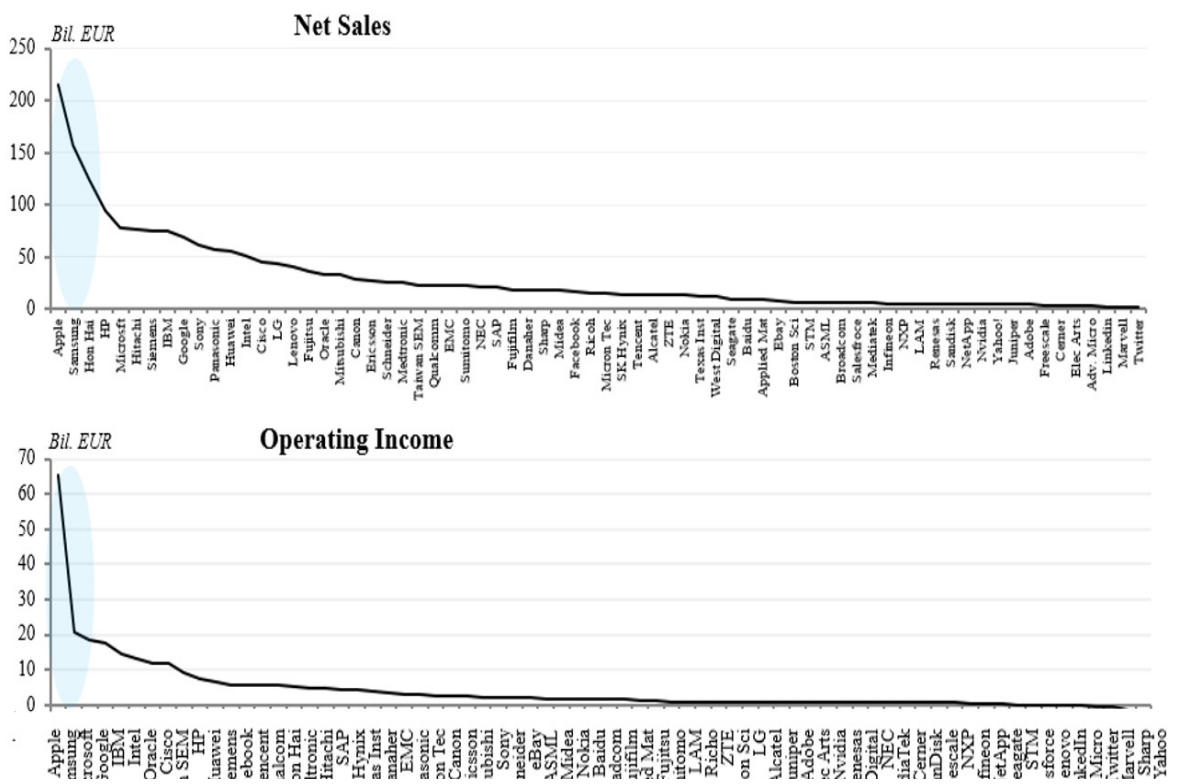

Figure 9. Emergence of "mutation” firms with outlying behavior (70 global ICT firms in 2016).

Table 3 Outlying features of top 5 global ICT firms.

\begin{tabular}{|c|c|c|c|c|c|c|c|}
\hline \multicolumn{2}{|c|}{ Rank } & \multicolumn{2}{|c|}{ R\&D } & \multicolumn{2}{|c|}{ Sales } & \multicolumn{2}{|c|}{ Operating income } \\
\hline \multicolumn{2}{|c|}{1} & Samsung & (1969) & Apple & (1976) & Apple & (1976) \\
\hline \multicolumn{2}{|c|}{2} & Intel & (1968) & Samsung & (1969) & Samsung & (1969) \\
\hline \multicolumn{2}{|c|}{3} & Google & (1998) & Hon Hai & (1974) & Microsoft & (1975) \\
\hline \multicolumn{2}{|c|}{4} & Microsoft & (1975) & $\mathrm{HP}$ & (1939) & Google & (1998) \\
\hline \multicolumn{2}{|c|}{5} & Huawei & (1987) & Microsoft & (1975) & IBM & (1911) \\
\hline \multirow{2}{*}{ Ratio } & $\begin{array}{l}\text { Top } 1 \\
\text { and } 5\end{array}$ & \multicolumn{2}{|c|}{1.5} & \multicolumn{2}{|c|}{2.8} & \multicolumn{2}{|c|}{4.5} \\
\hline & $\begin{array}{l}\text { Top } 1 \\
\text { and } 10\end{array}$ & \multicolumn{2}{|c|}{2.6} & \multicolumn{2}{|c|}{3.5} & \multicolumn{2}{|c|}{8.9} \\
\hline
\end{tabular}

The figures in parentheses indicate the year of foundation.

\subsubsection{Avoidance of Bias by Gigantic Firms in SLG Estimation}

In order to explores a new insight for global ICT firms for their transformative strategy against productivity decline, objective state and prospect of productivity and development trajectory of global ICT firms general (not certain particular noting firms) should be analyzed not biased by particular gigantic "mutation" firms. However, since $S L G$ function depends on fixed carrying capacity common to all firms analyzed (see equation (8)) resulting in biased estimate by highest development state in gigantic firms.

While Fig. 8suggests $S L G$ based $R$-driven development trajectory for 500 global ICT firms, it is 
International Journal of Managing Information Technology (IJMIT) Vol.10, No.1, February 2018

feared to be biased by several gigantic firms with extraordinary high level of sales such as Apple, Samsung and Hon Hai. They share more than Euro 100billion sales in 2016 while majority of 500 firms belong to the sales level below Euro 60 billion.

Aiming at avoiding such bias by certain gigantic firms, comparative assessment of the bias of gigantic firms in distorting $R$-driven development of the majority of 500 global ICT firms was conducted by treating gigantic firms that may distort such behavior as dummy variable in the $S L G$ function. This comparative assessment identifies such gigantic firms which have high variance from the general behavior of global ICT firms, and measures the magnitude of that variance, without which the highest representation of $R$-driven development trajectory can be analyzed by using $S L G$ function. Table 4 summarizes the result of the comparative assessment.

Table 4. Comparison of bias of gigantic firms in distorting $R$-driven $S L G$-based sales growth trajectory in majority of 500 global ICT firms (2016).

$$
S=\frac{N}{1+b e^{-a R}}+c D
$$

where $N$ : carrying capacity, $a, b, c$ : coefficients, $D$ : dummy variable ( $D=1$ for designated outlier firms, $D=0$ for other firms).

\begin{tabular}{|c|c|c|c|c|c|c|}
\hline & $N$ & $a$ & $b$ & $c$ & adj. $R^{2}$ & $D$ (Gigantic firms treated by dummy variable) \\
\hline$A$ & $\begin{array}{l}68.72 \\
(17.92)\end{array}$ & $\begin{array}{c}1.21 \\
(10.70)\end{array}$ & $\begin{array}{l}16.36 \\
(20.02)\end{array}$ & $\begin{array}{l}96.87 \\
(22.07)\end{array}$ & 0.695 & Apple \\
\hline$B$ & $\begin{array}{l}58.24 \\
(18.04)\end{array}$ & $\begin{array}{c}\frac{1.44}{1.44} \\
(10.31)\end{array}$ & $\begin{array}{l}(15.55 \\
(18.75)\end{array}$ & $\begin{array}{l}97.82 \\
(25.09)\end{array}$ & 0.734 & Apple, Samsung \\
\hline C & $\begin{array}{l}59.62 \\
(17.39)\end{array}$ & $\begin{array}{c}1.32 \\
(10.98) \\
\end{array}$ & $\begin{array}{l}15.91 \\
(21.87) \\
\end{array}$ & $\begin{array}{l}99.09 \\
(29.74) \\
\end{array}$ & 0.784 & Apple, Samsung, Hon Hai. \\
\hline$D$ & $\begin{array}{l}61.23 \\
(16.77)\end{array}$ & $\begin{array}{c}1.01 \\
(10.72)\end{array}$ & $\begin{array}{l}13.30 \\
(21.63) \\
\end{array}$ & $\begin{array}{l}99.69 \\
(29.22)\end{array}$ & 0.780 & Apple, Samsung Hon Haj, HP \\
\hline$E$ & $\begin{array}{l}50.38 \\
(15.95)\end{array}$ & $\begin{array}{l}1.33 \\
(9.41)\end{array}$ & $\begin{array}{l}12.71 \\
(1793)\end{array}$ & $\begin{array}{l}90.72 \\
(27.83)\end{array}$ & 0.766 & Apple, Samsung Hon Hai, HP, Microsoft \\
\hline$F$ & $\begin{array}{l}53.91 \\
(14.63)\end{array}$ & $\begin{array}{l}1.03 \\
(927) \\
\end{array}$ & $\begin{array}{l}11.99 \\
(18.87)\end{array}$ & $\begin{array}{l}87.80 \\
(27.79)\end{array}$ & 0.766 & Apple, Samsung Hon Hai, HP, Microsoft, Hitachi \\
\hline
\end{tabular}

"In addition to the above firms, Amazon and McKesson are included as outliers.

The figures in parentheses indicate t-statistics: All are significant at the $1 \%$ level.

Table 4 indicates that the case $C$ (sales top 3 gigantic firms, Apple, Samsung and Hon Hai distort 500 global ICT firms' $S L G$ trajectory most significantly) demonstrates statistically most significant. This $R$-driven $S L G$-based sales growth trajectory demonstrates better explanation than that of operating income growth trajectory as compared with Table 5and supports the view that sales represents R\&D-driven digital value creation behavior in the 500 global ICT firms.

Table 5. $R$-driven $S L G$-based Operating Income Growth Trajectory in 500 Global ICT Firms (2016).

$$
O I=\frac{N}{1+b e^{-a R}}+c D
$$

\begin{tabular}{cccccl}
\hline$N$ & $a$ & $b$ & $c$ & adj. $R^{2}$ & $D$ \\
\hline 21.23 & 0.90 & 73.85 & 7.24 & 0.589 & Apple \\
$(18.44)$ & $(10.74)$ & $(13.82)$ & $(11.37)$ & & \\
\hline
\end{tabular}

The figures in parentheses indicate t-statistics: All are significant at the $1 \%$ level. 
International Journal of Managing Information Technology (IJMIT) Vol.10, No.1, February 2018

\subsection{Declining Trend In The Marginal Productivity Of ICT}

By conducting the similar assessments, Table 6compares the $S L G$ function in 2005 and 2016.

Table 6. Estimation of development trajectory of the 500 global ICT firmsin 2005 and 2016.

$$
S=\frac{N}{1+b e^{-a R}}+c D
$$

\begin{tabular}{ccccccl}
\hline & $\boldsymbol{N}$ & $\boldsymbol{a}$ & $\boldsymbol{b}$ & $\boldsymbol{c}$ & $\boldsymbol{a d j .} \boldsymbol{R}^{2}$ & \multicolumn{1}{c}{$\boldsymbol{D}$} \\
\hline \multirow{2}{*}{2005} & 53.80 & 1.55 & 22.02 & 42.63 & 0.734 & \multirow{2}{*}{ Dell } \\
& $(21.18)$ & $(16.96)$ & $(29.44)$ & $(18.13)$ & & \\
\hline \multirow{2}{*}{2016} & 59.62 & 1.32 & 15.91 & 99.09 & 0.784 & \multirow{2}{*}{ Samsung,Apple, Hon Hai } \\
\hline
\end{tabular}

The figures in parentheses indicate t-statistics: All are significant at the $1 \%$ level.

Based on the above estimates, marginal productivity of ICT was computed by utilizing equation (9). Fig. 10 demonstrates the marginal productivity of ICT in 500 global ICT firms corresponding to their R\&D expenditurein 2005 and 2016. Fig. 10 demonstrates explicit bi-polarization between high R\&D-intensive firms (HRIF: $D_{l}$ in Fig. 8) out of 500 global ICT firms and remaining low R\&D-intensive firms ( $L R I F: \mathrm{D}_{2}$ and $\mathrm{D}_{3}$ in Fig. 8). HRIFs have fallen into a vicious cycle between R\&D expenditure centered by ICT and its marginal productivity, as the former increase results in declining the latter. On the contrary, LRIF shave maintained a virtuous cycle, as R\&D increase leads to marginal productivity increase.HRIFs demonstrates the long tail phenomena [30].

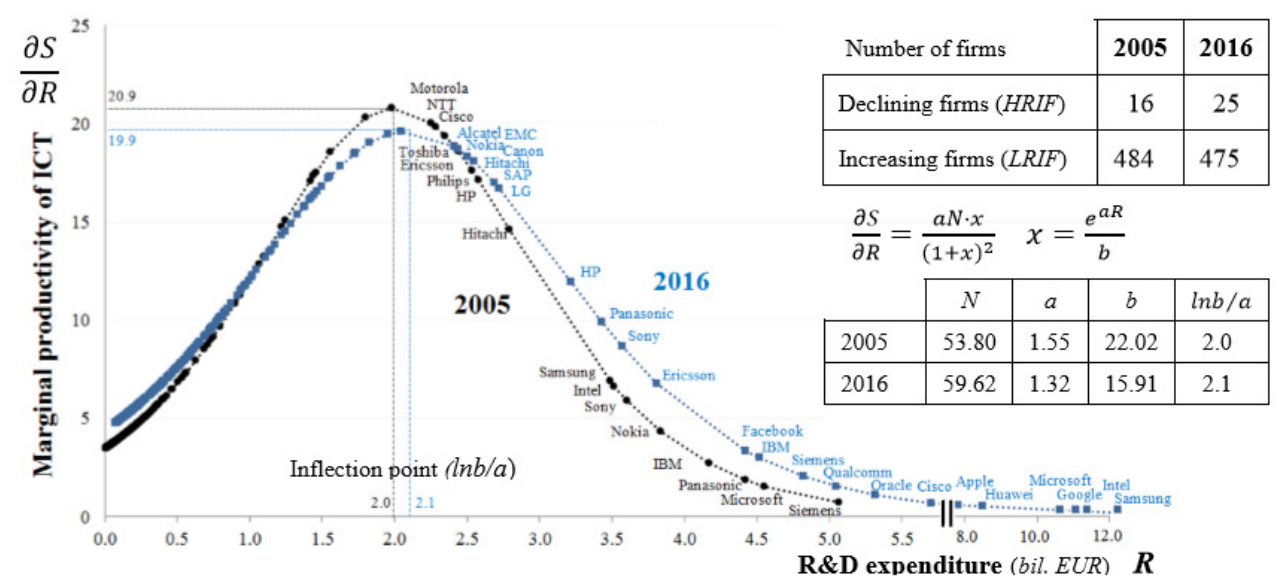

Figure 10. Comparison of marginal productivity of ICT in 500 global ICT firms (2005 and 2016).

Looking at Fig. 10, we note that the inflection point from marginal productivity enhance to decline shifted slightly higher from EUR 2.0 billion in 2005 to EUR 2.1 billion in 2016, corresponding to the increase in $R \& D$ expenditure during this period. However, the maximum level of marginal productivity of ICT at the inflection point decreased during this period, reflecting the declining trend in this productivity in global ICT firms.

Table 7 compares HRIFs that have fallen into a vicious cycle between $\mathrm{R} \& \mathrm{D}$ expenditure and marginal functionality of ICT between 2005 and 2016. Numbers of HRIFs have increased significantly from 16 in 2005 to 25 in 2016. Given the leading role that R\&D intensive global ICT firms initiates in the digital economy, this increase also provides an evidence of productivity decline in the digital economy stemmed from a trap in ICT advancement due to two-faced nature of 
International Journal of Managing Information Technology (IJMIT) Vol.10, No.1, February 2018

ICT. Table 7 also demonstrates such explicit shifts in HRIFs' business focus as from mechatronics (e.g., Siemens, IBM, Hitachi and Toshiba) to network and solutions (e.g., Samsung, Intel, Google, Huawei, Apple, Cisco).

Table 7. Comparison of HRIFswith R\&D Expenditure in 2005 and 2016.

\begin{tabular}{|c|c|c|c|c|}
\hline & \multicolumn{2}{|l|}{2005} & \multicolumn{2}{|l|}{2016} \\
\hline & Firm & $\begin{array}{l}\text { R\&D } \\
\text { (bil. EUR) }\end{array}$ & Firm & $\begin{array}{l}\text { R\&D } \\
\text { (bil. EUR) }\end{array}$ \\
\hline 1 & Siemens & 5.06 & Samsung Electronics & 12.53 \\
\hline 2 & Microsoft & 4.55 & Intel & 11.14 \\
\hline 3 & Panasonic & 4.42 & Google & 11.05 \\
\hline 4 & IBM & 4.17 & Microsoft & 11.01 \\
\hline 5 & Nokia & 3.83 & Huawei & 8.36 \\
\hline 6 & Sony & 3.60 & Apple & 7.41 \\
\hline 7 & Intel & 3.52 & Cisco Systems & 5.70 \\
\hline 8 & Samsung Electronics & 3.48 & Oracle & 5.32 \\
\hline 9 & Hitachi & 2.79 & Qualcomm & 5.04 \\
\hline 10 & Hewlett-Packard & 2.58 & Siemens & 4.82 \\
\hline 11 & Philips Electronics & 2.53 & IBM & 4.51 \\
\hline 12 & Ericsson & 2.44 & Facebook & 4.42 \\
\hline 13 & Toshiba & 2.42 & Ericsson & 3.81 \\
\hline 14 & Cisco Systems & 2.35 & Sony & 3.57 \\
\hline 15 & NTT & 2.28 & Panasonic & 3.43 \\
\hline 16 & Motorola & 2.25 & Hewlett-Packard & 3.22 \\
\hline 17 & & & LG Electronics & 2.72 \\
\hline 18 & & & SAP & 2.69 \\
\hline 19 & & & Hitachi & 2.54 \\
\hline 20 & & & Canon & 2.50 \\
\hline 21 & & & Nokia & 2.50 \\
\hline 22 & & & $\mathrm{EMC}$ & 2.44 \\
\hline 23 & & & Alcatel-Lucent & 2.41 \\
\hline 24 & & & Toshiba & 2.40 \\
\hline 25 & & & Amazon & $0.59 *$ \\
\hline
\end{tabular}

Order by level of R\&D expenditure.

* Amazon is included in the list as its market capitalization is conspicuous while R\&D investment is ranked $95^{\text {th }}$ in 2016 .

Table 8 compares contrast of sales growth rate between HRIFs and LFIFs over the period 2005-2016 which demonstrates that HRIF shave fallen into a stagnation of growth as a consequence of productivity decline while LRIF shave maintained sustainable growth.

Table 8. Contrast of sales growth rate between HRIFsand LRIFs(2005-2016) -Average of sales growth rate $(\%$ p.a).

High R\&D-intensive firms (HRIFs)

\begin{tabular}{lclccc} 
& Samsung & Google & Microsoft & Apple & Amazon \\
\hline $2005-2008$ & 14.5 & 72.6 & 13.3 & 38.5 & 25.5 \\
$2009-2012$ & 14.2 & 27.5 & 8.8 & 53.5 & 38.7 \\
$2013-2016$ & 9.7 & 24.0 & 8.7 & 27.5 & 28.0 \\
\hline
\end{tabular}

Low R\&D-intensive firms (LFIFs)

\begin{tabular}{cccccc} 
& $\begin{array}{c}\text { Electronic } \\
\text { Arts }\end{array}$ & $\begin{array}{c}\text { Taiwan } \\
\text { Semiconductor }\end{array}$ & Accenture & Kyocera & $\begin{array}{c}\text { Free } \\
\text { Scale }\end{array}$ \\
\hline $2005-2008$ & 1.9 & 9.7 & 0.8 & 0.1 & -1.5 \\
$2009-2012$ & 7.4 & 15.9 & 5.8 & 12.4 & 0.8 \\
$2013-2016$ & 8.0 & 21.6 & 14.6 & 18.6 & 4.0 \\
\hline
\end{tabular}


International Journal of Managing Information Technology (IJMIT) Vol.10, No.1, February 2018

\subsection{Countermeasures against Productivity Decline}

All these results support the supposition of the two-faced nature of ICT that leads to bipolarization, which is one of the critical structural sources of productivity decline in the digital economy.

Confronting such circumstances, HRIFs have been endeavoring to transform into a new business model that creates uncaptured GDP spontaneously by harnessing the vigor of soft innovation resourcessuch as supra-functionality beyond economic value [31], sleeping resources [32], trust [33], utmost gratification ever experienced [34], memory and dream [35], and untapped resources and vision [36] as demonstrated in Fig. 11.Majority of such soft innovation resources are beyond the GDP counting [37] [16].

\begin{tabular}{|l|l|}
\hline Samsung & $\begin{array}{l}\text { "User experiences through smart design and technology" } \\
\text { Inspire the world, create future design and technology innovation } \\
\text { (smartphones, art-frame TV, smart appliances) }\end{array}$ \\
\hline Google & $\begin{array}{l}\text { "Enabling overdrawing of information through search" } \\
\text { "One-click" access to the world's information } \\
\text { (Internet search, advertising, OS and platforms, Google apps) }\end{array}$ \\
\hline Apple & $\begin{array}{l}\text { "Harnessing the utmost gratification of consumer delight" } \\
\text { (Productivity and platform company for mobile-first and cloud-first world) }\end{array}$ \\
\hline Amazon & $\begin{array}{l}\text { "Personalized user experiences through top-quality products } \\
\text { To be the face of the earth to make great products } \\
\text { (Simple, user-friendly and better design; focus on innovation, collaboration, excellence) }\end{array}$ \\
\hline & $\begin{array}{l}\text { "Fusing physical and digital" } \\
\text { "Brging physical and digital }\end{array}$ \\
\hline
\end{tabular}

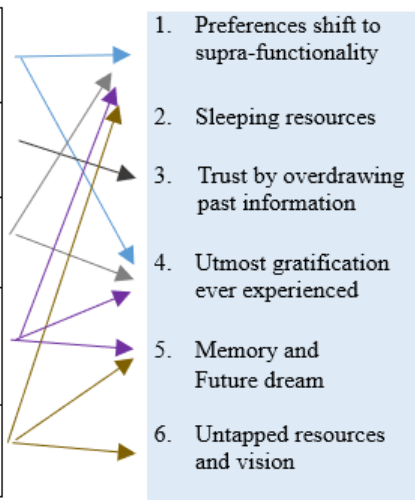

Figure 11. Transformative direction of HRIFs against productivity decline in the digital economy.

Such transformative direction suggests a new stream of digital solution-driven disruptive business model that creates uncaptured GDP spontaneously as illustrated in Fig. 12.

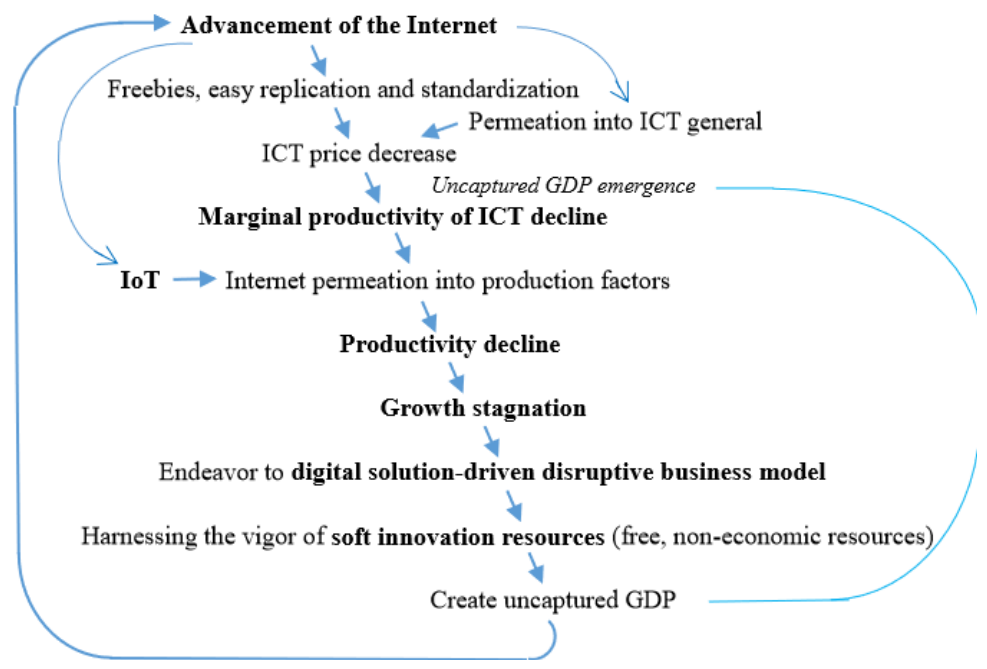

This model is essential for the sustainable growth in the digital economy. Since this model effectively utilizes soft innovation resources majority of which are beyond the GDP counting, this provides insightful suggestion to overcome the limitation of the GDP statistics in the digital economy.

Figure 12. Scheme of the new stream of digital solution-driven disruptive business model. 
International Journal of Managing Information Technology (IJMIT) Vol.10, No.1, February 2018

\section{CONCLUSION}

In light of an apparent productivity decline in the ICT advanced countries as a consequence of the advancement of the digital economy that reveals the limitation of GDP, structural sources of such unexpected decline and countermeasures against the critical circumstances were analyzed.

On the basis of national accounting framework and utilizing the findings obtained from the development trajectories of 500 global ICT firms, unknown dynamism creating uncaptured GDP and suggestion to improve the GDP statistics for measuring the digital economywere investigated. Noteworthy findings include:

(i) Productivity in industrialized countries has been confronted with an apparent decline resulting in the stagnation in their GDP growth in the digital economy.

(ii) This can be attributed to a trap in ICT advancement that stems from the two-faced nature of ICT resulting in bipolarizing the development trajectories of global ICT firms.

(iii) While relatively low R\&D-intensive firms have maintained a virtuous cycle between R\&D and marginal productivity of ICT increase, high R\&D-intensive firms have fallen into a vicious cycle as R\&D increase results in marginal productivity of ICT decline.

(iv) Such trend has been accelerated as digitalization proceeded and number of vicious cycle firms have significantly increased over the last decade.

(v) Confronting such circumstances, high R\&D-intensive firms have been endeavoring to transform into digital solution-driven disruptive business model by harnessing the vigor of soft innovation resources. This transformation leads to spontaneous creation of uncaptured GDP.

(vi) This model effectively utilizes soft innovation resources majority of which are beyond GDP counting and provides insightful suggestion to overcome the limitation of the GDP statistics in the digital economy.

These findings give rise to the following insightful suggestions for optimal trajectory management and improving the GDP statistics for measuring the advancement of the digital economy:

(i) Productivity paradox in the digital economy that reveals the limitation of the GDP statistics in measuring the advancement of digital economy should be realized.

(ii) Given the structural sources of a productivity decline leading to such paradox, measurement of uncaptured GDP, and efforts against ICT price decrease, should be endeavored.

(iii) Given that leading global ICT firms have been endeavoring to create new survival strategy in the face of increasing dependence on uncaptured GDP, forefront of their endeavor should be investigated.

(iv) In this context, management system harnessing the vigor of soft innovation resources should be further explored.

(v) Based on the above endeavors, attempts to apply such dynamism of harnessing the vigor of soft innovation resources to overcome the limitation of the GDP statistics in measuring the advancement of the digital economy should be conducted.

This analysis provides new insights for identifying digital solution-driven disruptive business model amidst the advancement of the digital economy with productivity decline.

Future works should focus on international and historical reviews of success stories of gross GDP management encompassing both captured and uncaptured GDPat the national and industrial levels. The development of public policies based on the gross GDP concept should be prioritized. 


\section{ACKNOWLEDGEMENTS}

The research leading to these results is the part of a project: Platform Value Now: Value capturing in the fast emerging platform ecosystems, supported by the Strategic Research Council at the Academy of Finland [grant number 293446].

Authors are grateful to Dr Kashif Naveed and Dr Shino Iwami (University of Jyvaskyla) for their data construction and bibliometric analysis.

\section{REFERENCES}

[1] Tapscott, D., (1994)The Digital Economy: Promise and Peril in the Age of Networked Intelligence, McGraw-Hill, New York.

[2] Department of Broadband, Communications and the Digital Economy (DBCDE), (2009)Digital Economy Future Directions,DBCDE, Camberra.

[3] OECD, (2016)OECD Observer: The Digital Economy, OECD, Paris.

[4] US Council on Competitiveness., (2016)No Recovery: An Analysis on Long-term U.S. Productivity Decline, Washington, D.C.

[5] The World Bank, (2016) Digital Dividends, The World Bank, Washington D.C.

[6] Ahmad, N.\& Schreyer, P., (2016)“Are GDP and Productivity Measures up to the Challenges of the Digital Economy?’International Productivity Monitor, Vol. 30, Spring, pp 4-27.

[7] Moriya, K., (2017)“On the OECD/WPNA: Challenges to the Digital Economy in Official Statistics and Countries' Reports on 2008SNA Issues,"Quarterly Journal of National Accounts,Vol. 162, pp 61-78.

[8] International Monetary Fund (IMF), (2017)Measuring the Digital Economy: IMF Statistical Forum. IMF, Washington D.C.

[9] Solow. R., (1987)“We'd Better Watch Out, Review of S.S. Cohen and J. Zysman, Manufacturing Matters: The Myth of the Post-industrial Economy,"New York Times Book Review, 36.

[10] Brynjolfsson, E., (1993)“Productivity Paradox of Information Technology,"Communications of the Association for Computing Machinery, Vol.36, No. 12, pp 66-77.

[11] Rifkin, J., (2011)The Third Industrial Revolution: How Lateral Power Is Transforming Energy, the Economy, and the World, Macmillan, New York.

[12] Cowen, T., (2011)The Great Stagnation, Penguin, New York.

[13] Brynjolfsson, E.\& McAfee, A., (2011)Race against the Machine. Digital Frontier, Lexington, MA.

[14] Brynjolfsson, E.\& McAfee, A., (2014) The Second Machine Age, Norton \& Company, New York.

[15] Lowrey, A., (2011)Freaks, Geeks, and GDP.Retrieved June 20, 2017, from http://www.slate.com/articles/business/moneybox/2011/03/freaks_geeks_and_gdp.html.

[16] Watanabe, C., Naveed, K.\&Zhao, W., (2015)“New Paradigm of ICT Productivity: Increasing Role of Un-captured GDP and Growing Anger of Consumers,’Technology in Society, Vol.41, pp 21-44.

[17] Watanabe, C., Naveed, K.\&Neittaanmäki, P., (2015)”Dependency on Un-captured GDP as a Source of Resilience beyond Economic Value in Countries with Advanced ICT Infrastructure: Similarities and Disparities between Finland and Singapore,’Technology in Society,Vol. 42, pp 104-122.

[18] Watanabe, C., Naveed, K., Neittaanmäki, P.\&Tou, Y., (2016)"'Operationalization of Un-captured GDP: The Innovation Stream under New Global Mega-trends,’Technology in Society, Vol.45, pp 58-77. 
International Journal of Managing Information Technology (IJMIT) Vol.10, No.1, February 2018

[19] EU, (2017)The Internet of Things: Digital Single Market. EU, Brussels.

[20] Internet Society, (2015) The Internet of Things: An Overview. Retrieved August 05, 2017, from https://www.internetsociety.org/doc/iot-overview.

[21] McKinsey Global Institute, (2015) The Internet of Things: Mapping the Value beyond the Hype, McKinsey \& Company, San Francisco.

[22] Kajikawa, Y., Ohno, J., Takeda, Y., Matsushima, K.\&Komiyama, H., (2007)“Creating an Academic Landscape of Sustainability Science: An Analysis of the Citation Network," Sustainability Science, Vol. 2, No. 2, pp 221-231.

[23] Innovation Policy Research Center (IPRC), (2013) Academic Landscape System. Retrieved April 09, 2017, from http://academic-landscape.com/.

[24] Newman, M.E.J., (2004)“Fast Algorithm for Detecting Community Structure in Networks,"Physical Review E., Vol. 69 (66133).

[25] International Monetary Fund (IMF), (2017)World Economic Outlook Database, IMF, Washington, D.C.

[26] World Economic Forum (WEF), (2013)The Global Information Technology Report, 2013, WEF, Geneva.

[27] Naveed, K., Watanabe, C.\&Neittaanmäki, P., (2017)"The Transformative Direction of Innovation toward an IoT-based Society: Increasing Dependency on Uncaptured GDP in Global ICT Firms,'Technology in Society, Vol.53 (in print).

[28] European Commission, Joint Research Center, (2004-2016)The EU Industrial R\&D Investment Scoreboard. European Commission, Brussels.

[29] Devezas, T.C., Linstone, H.A.\& Santos, H.J.S., (2005)“The Growth Dynamics of the Internet and the Long Wave Theory,’Technological Forecasting and Social Change, Vol. 72, pp 913-935.

[30] Anderson, C., (2006) The Long Tail: Why the Future of Business is Selling Less of More, Hyperion Books, New York.

[31] McDonagh, D., (2008) Satisfying Needs beyond the Functional: The Changing Needs of the Silver Market Consumer. Presented at the International Symposium on the Silver Market Phenomenon Business Opportunities and Responsibilities in the Aging Society, Tokyo, Japan.

[32] Watanabe, C., Naveed, K., Neittaanmäki, P. \&Tou, Y., (2016) "Co-evolution of Three Mega Trends Nature Uncaptured GDP: Uber's Ride-sharing Revolution,'Technology in Society, Vol.46, pp 164-185.

[33] Watanabe, C., Naveed, K., Neittaanmäki, P. \& Fox, B., (2016) "Co-evolution between Trust in Teachers and Higher Education toward Digitally-rich Learning Environments,"Technology in Society, Vol.48, pp 70-96.

[34] Watanabe, C., (2013) "Innovation-consumption Co-emergence Leads a Resilience Business,”Innovation Supply Chain Management, Vol.7, No. 3, pp 92-104.

[35] Naveed, K., Watanabe, C. \&Neittaanmäki, P., (2017) "Co-evolution between Streaming and Live Music Leads a Way to the Sustainable Growth of Music Industry: Lessons from the US Experiences," Technology in Society, Vol.50, pp 1-19.

[36] Watanabe, C., Naveed, K. \&Neittaanmäki, (2017) "ICT-driven Disruptive Innovation Nurtures Uncaptured GDP: Harnessing Woemen's Potential as Untapped Resources.,'Technology in Society, Vol.51, pp 81-101.

[37] Japan Cabinet Office (JCO), (2012)National Survey of Lifestyle Preferences, JCO, Tokyo. 
International Journal of Managing Information Technology (IJMIT) Vol.10, No.1, February 2018

\section{AUTHORS}

Chihiro Watanabe graduated from the University of Tokyo, Japan, and is currently Professor Emeritus at the Tokyo Institute of Technology, research professor at the University of Jyväskylä, Finland, and a research scholar at the International Institute for Applied Systems Analysis (IIASA). (watanabe.c.pqr@gmail.com).

Kuniko Moriya graduated from AoyamaGakuin University, Japan, is currently Director of the Bank of Japan. (kuniko.moriya@boj.or.jp).

Yuji Tou graduated from Tokyo Institute of Technology, Japan, and is currentlyspecially appointed associate professor at Tokyo Institute of Technology, Japan (tou.yuji@gmail.com).

PekkaNeittaanmäki graduated from the University of Jyväskyläwith a degree in Mathematics. He is currently Professor of the Faculty of Information Technology, University of Jyväskylä, Finland. (pekka.neittaanmaki@jyu.fi). 